\title{
INFORMAL LEARNING: CONTRIBUTIONS OF TECHNOLOGY IN A DIGITAL SOCIETY
}

\author{
Iris Estévez, Alba Souto-Seijo, Mercedes González-Sanmamed, Verónica Iglesias, \\ University of A Coruña, Spain
}

\section{Introduction}

We live in a complex society, with multiple questions and challenges. Since computers and the Internet invaded our lives, our way of communicating and relating has changed drastically. The digital revolution is causing continuous changes in different contexts, and education is one of them. Nowadays, knowledge has expiration date, for this reason citizens have to assume that training is not a one-time activity that takes place at a certain time, but that life consists of a continuous learning.

This fact, perhaps, in the case of teachers, has a greater importance, because they not only have the need to learn, but also the responsibility to teach in a changing environment. Different educational institutions must respond to the new challenges posed by the information society, but this formal education is not enough. According to GonzálezSanmamed, Sangrà, Souto-Seijo, Santos, and Estévez (2018), learning does not take place linearly or in specific spaces; nor can it be limited to the closed parameters of the formal training proposals. Nowadays, there are many possibilities to train and learn. For this reason, informal training models are becoming increasingly important, in addition to the classical formal training models.

Now we will explain what is meant by formal, non-formal and informal training. On the one hand, formal training takes place in institutions that are specifically dedicated to training and is intentional (Martín, 2013). On the other hand, non-formal training includes those activities offered by various institutions that are not explicitly educational but contain important components to favour the learning process (Cobo \& Moravec, 2011). These activities are characterized by having a more flexible format. Finally, informal training corresponds to the daily learning that occurs spontaneously in everyday situations (González-Sanmamed, Sangrà, Souto-Seijo, \& Estévez, 2018). It is important to emphasize that the ideal is to integrate all these training opportunities (Cross, 2007), because it will be what facilitates the complicated task of responding to the training and personal and professional updating needs that are presented to us.

At this point, we will explain what is the current situation of teacher training in Spain. Until recently, teacher training was synonymous with face-to-face training courses, although this reality has been changing thanks to the possibilities offered by technology (Marcelo, 2002). 
Thus, on-line training and blended-training have been added, naturally, to the training that traditionally was done face to face (Paniagua, Luengo, Torres Carvalho, \& Casas, 2017).

Although some studies highlight the importance of new training modalities and the relevance they have progressively in the day-to-day work of teacher education (Nunes \& Meneses, 2014), it is also true that the most classical training is still preferred by them (Paniagua, Luengo, Torres, Carvalho, \& Casas, 2017). Therefore, the specific objectives that structure this study are the following:

- Identify which are the activities of lifelong learning, with or without a technological base, more frequent within the informal contexts of learning.

- Study the reasons that cause the involvement of teachers in the informal-training activities.

\section{Methodology}

This study, of a quantitative nature, is developed through a non-experimental-descriptive design (McMillan \& Schumacher, 2005). Following, the information related to the participants, the instrument used, the procedure followed and the data analysis will be explained in more detail.

\section{Participants}

The sample consisted of 73 teachers of Primary Education of 11 public schools located in A Coruña, a city in the north of Spain. This was done by a convenience sampling (Schreier, 2018). A $27.4 \%$ of the participants were men and $72.6 \%$ were women. In a $16.4 \%$ the average age is between 25 and 35 years old, $47.9 \%$ are between 36 and 50 years old and $35.6 \%$ are over 51 years old.

In relation to their professional experience it should be noted that a $43.8 \%$ had between 21 and 35 years of experience as a teacher, the $28.8 \%$, had an experience of between 11 and 20 years, the $13.7 \%$ had between 5 and 10 years of experience and, finally, $8.2 \%$ had an experience of fewer than 5 years.

\section{Instruments}

The instrument used for data collection was a self-created questionnaire. The characteristics of the questionnaire, among which are versatility, efficiency, and generality (McMillan, 2012), have been what led us to select this instrument to collect the information. For its validation, a system based on the judgment of the experts, which consists of an assessment of the instrument, was used (Escobar-Pérez \& Cuervo-Martínez, 2008). In addition, the information provided by the expert judgment was complemented by a pilot study. In these study, participated teachers from the Primary Education stage, because we could easily access.

The questionnaire was divided into 6 dimensions, although to carry out this study we focused on two of them. The first of these dimensions refers to the different types of informal activities that teachers carry out to develop themselves professionally, and the second is linked 
to the different reasons, which are behind the participation of Primary Education teachers, in this type of informal training activities. In the first one, thirty items are differentiated; and in the second, twelve items. Both have a Likert response scale from one to four. First scale response is: 1 - never, 2 - almost never, 3 - almost always and 4 - always. In addition, second scale response is: 1 - totally disagree, 2 - disagree, 3 - agree, 4 - totally agree.

\section{Process}

In the first place, the school management, where the questionnaire was intended to be applied, were informed of the study purpose. Once their consent was obtained, the information was collected. Thus, the questionnaire was delivered in person to the faculty of the different schools. The way their doubts are resolved and the anonymity and confidentiality of the data were guaranteed.

\section{Data analysis}

To carry out the statistical analysis, was used the computer program called SPSS. It started with an exploratory analysis, which allows us to evaluate the quality and distribution of the data (asymmetry and kurtosis), determine the summary measures (mode, media, and median), and calculate the dispersion measures (variance and range). In addition, we did descriptive and frequency analysis, in order to know the average score and percentages of each variable.

\section{Results}

The first objective was to identify what are the permanent training activities, with or without a technological base, more frequent within the informal learning contexts.

Attending now to this objective, we intend to identify which are the most frequent activities within the informal learning contexts. Some of the activities are based on the use of ICT and others are not, therefore, we differentiate both groups, to see if there are significant differences in the realization of both. For this, we have calculated the means of all the variables corresponding to informal activities, forming a group of activities with a technological base and another group of activities without a technological base.

The means for each variable, of the group of activities without a technological base, are the following: Self-reflection on the daily experience $(\bar{x}=3.19)$; reflection with classmates on the daily experience $(\bar{x}=3.16)$; reflection with colleagues from other centres on daily experiences $(\bar{x}=2.47)$; informal meetings with other professionals (communities of practice, interest groups, ...) $(\bar{x}=2.08)$; visiting to other classrooms and / or other centres $(\bar{x}=1.93)$; visiting museums $(\bar{x}=2.49)$; visiting exhibitions $(\bar{x}=2.49)$; periodic consultations / printed professional journals $(\bar{x}=2.27)$; periodic consultations / printed scientific journals $(\bar{x}=2.18)$; consulting professional printed books $(\bar{x}=2.36)$; consulting printed books of scientific, cultural or literary content $(\bar{x}=$ $2.34)$, consult printed academic reports $(\bar{x}=2.26)$; informal conversations with relatives $(\bar{x}=2.16)$; informal conversations with friends $(\bar{x}=2.40)$; informal conversations with colleagues $(\bar{x}=2.79)$; elaboration of classroom resources/materials $(\bar{x}=3.01)$; use of material 
resources for the classroom $(\bar{x}=3.08)$; design of specific work plans $(\bar{x}=2.59)$; exchange of experiences $(\bar{x}=2.60)$.

The average direct scores for the group of variables with a technological base are shown below: internet searches $(\bar{x}=2.51)$; internet tutorials $(\bar{x}=2.60)$; digital library consultation $(\bar{x}=2.53)$; work with digital books $(\bar{x}=2.53)$; consult digital materials $(\bar{x}=2.67)$; participation in digital social networks $(\bar{x}=1.93)$; development of blogs $(\bar{x}=1.96)$; search of blogs $(\bar{x}=2.68)$; search in open resource repositories $(\bar{x}=2.33)$; participation in a MOOC (mass open online courses $(\bar{x}=1.40)$; mass media: $T V$, cinema,... $(\bar{x}=2.37)$.

Following, Figure 1 is presented to summarize graphically the aforementioned data: 


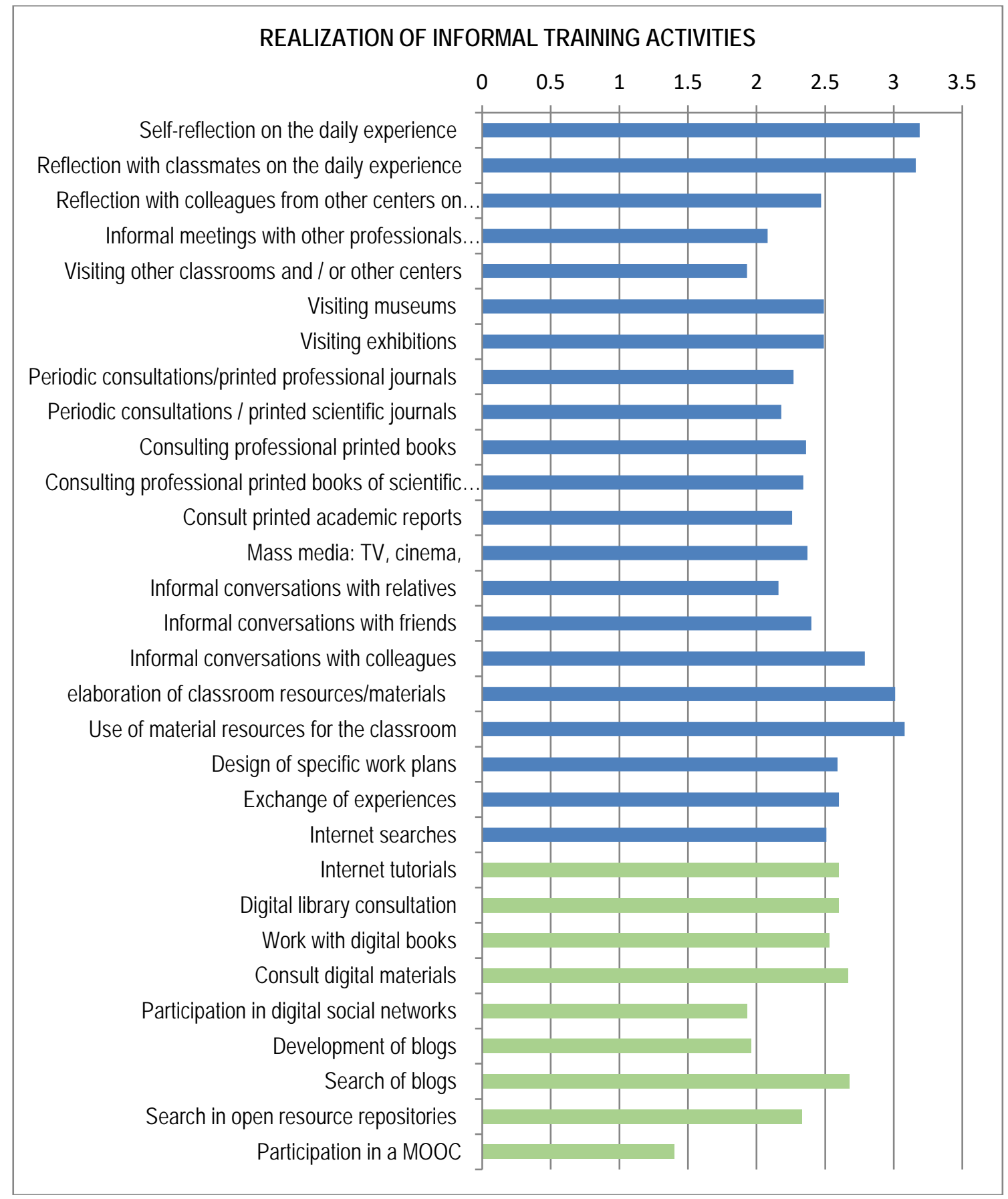

Figure 1. Frequency of realization of informal training activities

As can be seen in Figure 1, the most unusual informal training activity is participation in Mass Open Online Courses (MOOC); In fact, if we turn to the frequency analysis of this variable, we can see how $49 \%$ of the participants in our study have never attended a MOOC. On the other hand, the most important activity carried out by the Primary Education teachers, in order to improve their professional development, is the self-reflection on the daily experience with an average of 3.19. If we resort again to frequency analysis, but this time focusing on this last variable, we observe that $63.17 \%$ of the sample very often performs this type of informal training activity. 
If we focus on the results, differentiating in activities with a technological base, and without a technological base, we find that the activity with the digital base that is carried out most frequently, among the teachers of Primary Education, is the Consultation of Blogs $(\bar{x}=2.68)$. The one that participates to a lesser extent is in the realization of MOOC $(\bar{x}=1.40)$. It should also be noted that another of the activities in which teachers are involved to a lesser extent to develop professionally is the Blogs Design and development $(\bar{x}=1.96)$.

Among the activities without a technological base, that teachers perform to keep themselves updated, as the most frequent, we can find self-reflection on daily experience $(\bar{x}=3.19)$; and that which is established as less frequent within this group is the visit to other classrooms and/or other centres $(\bar{x}=1.93)$.

In addition, the second objective was related with the reasons behind the performance of informal activities by teachers. We propose twelve general possible reasons that could had teachers to carry out this kind of training. In the following table, we present descriptive statistics of each variable.

Table 1: $\quad$ Reasons for carrying out informal training activities.

\begin{tabular}{|c|c|c|c|c|c|c|c|c|}
\hline & $\mathrm{N}$ & $\mathrm{R}$ & Min & Max & $\bar{x}$ & TD & Asim & Curt. \\
\hline To be better professionally & 73 & 3 & 1 & 4 & 3.07 & 1.262 & -.900 & -.972 \\
\hline $\begin{array}{l}\text { Because I have deficiencies in my } \\
\text { initial training }\end{array}$ & 73 & 3 & 1 & 4 & 2.16 & 1.000 & .173 & -1.224 \\
\hline To help my students & 73 & 3 & 1 & 4 & 2.92 & 1.288 & -.684 & -1.302 \\
\hline To interact with other colleagues & 73 & 3 & 1 & 4 & 2.45 & 1.236 & -.023 & -1.628 \\
\hline To innovate in my teaching methods & 73 & 3 & 1 & 4 & 2.90 & 1.271 & -.650 & -1.309 \\
\hline $\begin{array}{l}\text { To earn points to advance in my } \\
\text { career }\end{array}$ & 73 & 3 & 1 & 4 & 1.45 & .943 & 1.826 & 1.812 \\
\hline $\begin{array}{l}\text { To have many accreditations in my } \\
\mathrm{CV}\end{array}$ & 73 & 3 & 1 & 4 & 1.26 & .646 & 2.555 & 5.900 \\
\hline $\begin{array}{l}\text { To share information and knowledge } \\
\text { with my colleagues }\end{array}$ & 73 & 3 & 1 & 4 & 2.23 & 1.161 & .240 & -1.461 \\
\hline $\begin{array}{l}\text { To exchange resources with my } \\
\text { colleagues }\end{array}$ & 73 & 3 & 1 & 4 & 2.32 & 1.165 & .111 & -1.503 \\
\hline $\begin{array}{l}\text { To adapt myself to the new social and } \\
\text { education changes }\end{array}$ & 73 & 3 & 1 & 4 & 2.47 & 1.226 & -.128 & -1.614 \\
\hline $\begin{array}{l}\text { To learn new educational } \\
\text { methodologies }\end{array}$ & 73 & 3 & 1 & 4 & 2.53 & 1.365 & -.074 & -1.845 \\
\hline To be updated & 73 & 3 & 1 & 4 & 2.67 & 1.334 & -.307 & -1.713 \\
\hline
\end{tabular}

As we can see in Table 1, the most important reason to carry out informal training for Primary teachers is to be better professionally $(\bar{x}=3.07)$, followed by: to help students $(\bar{x}=2.92)$, to innovate in teaching methods $(\bar{x}=2.92)$, and to be updated $(\bar{x}=2.67)$. Nevertheless, we need to highlight the reasons least valued by teachers to carry out this type of training are to earn points to advance in professional career $(\bar{x}=1.45)$ and to have many accreditations in the $C V(\bar{x}=1.26)$. 


\section{Conclusions}

From the results previously showed, we can conclude that the participants of our study do not prefer the activities based on technology to continue learning, it is still preferred the face-toface training, according with Nunes and Meneses (2014). However, in the same way as Paniagua, Luengo, Torres Carvalho, and Casas (2017) said, the ICT became in an important tool to help teachers stay up-to-date. Online and blended training was added to the traditional face-to-face, but they have not taken their place.

The training of teachers as competent subjects for the pedagogical use of ICT has received special attention in recent years. Thus, UNESCO (2008) offers a proposal for teacher training in which it is clear that this should not only be aimed at acquiring the skills to use technological tools, but should prioritize the acquisition of skills and knowledge, both theoretical and procedural, to use them in an innovative and creative way in teachinglearning situations (Area, Borrás, \& Sannicolás, 2014). That is to say, the training of teachers should not be reduced to the acquisition of instrumental competences for the use of technology, something that does occur in the Spanish context (Sancho et al., 2008).

It seems that the use of Technology for professional development has a fundamentally instrumental use for Primary Education teachers. In addition, it is assumed that they acquire the role of consumers of information, instead of producers of it. This seems to be reflected when the teachers determine as an activity (with a technological base) the frequency of the consultation of blogs, and, nevertheless, as one of the least frequent the elaboration of blogs. One of the reasons behind the fact that, almost half of the sample (49\%) has never made a MOOC, may be the lack of knowledge of this type of training alternatives.

The conclusion around the second objective of this study, point out the reasons behind performing of informal training by Primary Schools teachers. The results, we have obtained, show that teachers decide to involve in this type of training in order to be better professionals, therefore, to help their students, to innovate their pedagogical methods and to be updated. All this reasons are related to intrinsic motivation. Thus, it seems that informal training, as conversations with colleagues or friends, meetings with other professionals, participating in social networks, self-training, consult digital materials, etc. are more related with intrinsic motivation. Although, on the other hand, the reasons least valued by teachers for carrying out informal activities are related to the acquisition of certificates, or any kind of external rewards. Due to this fact, we deduce that, carrying out informal training is more associated with intrinsic motivation than to extrinsic one. It has sense in the way that, teachers maybe prefer getting involved in other types of training, like formal or non-formal, in order to get external rewards. For instance, a teacher who wants to get a French language certificate, he will probably opt for a formal French language-training course, instead of doing practice sessions with a friend who knows the language.

Finally, it is necessary to comment on the limitations of this study. Fundamentally overwhelmed by the number of participants in the study. The self-report instrument can also 
create biases in the results. On the other hand, we propose some future research lines that could be based on deepening the data and performing correlational or inferential analyses.

\section{References}

Area, M., Borrás, J. B., \& Sannicolás, B. (2014). La formación del maestro 2.0: el aprendizaje por tareas en entornos b-learning. Revista Interuniversitaria de Formación del Profesorado, 28(1), 51-66.

Cobo, C. \& Moravec, J. (2011). Aprendizaje Invisible. Hacia una nueva ecología de la educación. Barcelona: Publicacions i Edicions de la Universitat de Barcelona. Retrived from:

http://www.publicacions.ub.edu/ejecuta_descarga.asp? codart $=07458 \& \mathrm{mp}=43 \mathrm{~L} 41$ o31B75I $\&$ formato $=\mathrm{pdf}$

Cross, J. (2007). Informal Learning: Rediscovering the Natural Pathways that Inspire Innovation and Performance. San Francisco: Pfeiffer.

Escobar-Pérez, J., \& Cuervo-Martínez. A. (2008). Validez de contenido y juicio de expertos: una aproximación a su utilización. Avances en medición, 6, 27-36.

González-Sanmamed, M., Sangrà, A., Souto-Seijo, A., \& Estévez, I. (2018). Ecologías de aprendizaje en la Era Digital: desafíos para la Educación Superior. Publicaciones, 48, 11-38. http://doi.org/10.30827/publicaciones.v48i1.7329

González-Sanmamed, M., Sangrà, A., Souto-Seijo, A., Santos, F., \& Estévez, I. (2018). Learning Ecologies Oriented to the Professional Development of University Teachers. Proceedings of the 10 ${ }^{\text {th }}$ EDEN Research Workshop, Barcelona, 398-407.

Marcelo, C. (2002). La formación inicial y permanente de los educadores. En Consejo Escolar del Estado (Ed.), Los educadores en la sociedad del siglo XXI (pp.161-194). Madrid: MECD.

Martín, R. B. (2013). Contextos de aprendizaje. Formales, no formales e informales. IKASTORRATZA e-Revista de Didáctica, 12, 1-14. Retrieved from http://www.ehu.eus/ikastorratza/12_alea/contextos.pdf

McMillan, J. H. (2012). Educational Research: Fundamentals for the consumer (6 $6^{\text {th }}$ ed.). Boston: Pearson.

McMillan, J. H., \& Schumacher, S. (2005). Investigación Educativa. Una introducción conceptual $\left(5^{\text {th }}\right.$ ed.). Madrid: Pearson.

Nunes, R., \& Meneses, A. (2014). Facebook's contribution in the process of collaborative learning. Proceedings of the $3^{\circ}$ Congreso Ibero-Americano en Investigación Cualitativa, 62.

Paniagua, A., Luengo, R., Torres Carvalho, J. L., \& Casas, L. M. (2017). Blended learning en la formación permanente del profesorado. Aportaciones de asesores de formación sobre modalidades formativas. RED. Revista de Educación a Distancia, 52, a3.

http://dx.doi.org/10.6018/red/52/3 
Sancho, J. M., Ornellas, A., Sánchez, J. A., Alonso, C., \& Bosco, A. (2008). La formación del profesorado en el uso educativo de las TIC: una aproximación desde la política educativa. Praxis Educativa, 12(12), 10-22.

Schreier, M. (2018). Sampling and generalization. In U. Flick (Ed.), The sage handbook of qualitative data collection (pp. 84-97). London: Sage.

UNESCO (2008). ICT Competency Standards for Teachers. Retrieved from https://unesdoc.unesco.org/ark:/48223/pf0000156207

\section{Acknowledgments}

This study has been conducted in the framework of the research project (ECO4LEARN-HE), funded by the Ministry of Economy and Finance (Reference EDU2015-67907-R), and thanks to the funding received by one of the authors, Iris Estévez, in the FPI programme from the Ministry of Economy and Finance (BES-2016-077330). 